\title{
Burnaia Miller, 2001 (Gastropoda, Heterobranchia, Nudibranchia): a facelinid genus with an Aeolidiidae's outward appearance
}

\author{
Leila Carmona $^{1} \cdot$ Marta Pola $^{2} \cdot$ Terrence M. Gosliner $^{3} \cdot$ Juan Lucas Cervera $^{1}$
}

Received: 12 March 2015/Revised: 13 June 2015 / Accepted: 16 June 2015/Published online: 3 July 2015

(C) Springer-Verlag Berlin Heidelberg and AWI 2015

\begin{abstract}
In recent years, several morphological and molecular analyses have been undertaken to study the phylogenetic systematics of Aeolidiidae members. The monospecific genus Burnaia could not be included in the previous analysis, due to the lack of material. This study includes two specimens of Burnaia helicochorda from Australia and places them in their systematic position using two mitochondrial and one nuclear genes (COI and 16S, and $\mathrm{H} 3$, respectively). A description of its anatomy is also included with colour pictures of the animal and scanning electron micrographs of radula and jaws. Based on our results, B. helicochorda does not belong to Aeolidiidae since it appears nested among some facelinids.
\end{abstract}

Keywords Molluscan diversity · Molecular phylogeny · Taxonomy $\cdot$ Cladobranchia $\cdot$ Morphological convergence

Communicated by H.-D. Franke.

Leila Carmona

leila.carmona@uca.es

1 Departamento de Biología, Facultad de Ciencias del Mar y Ambientales, Campus de Excelencia Internacional del Mar (CEI-MAR), Universidad de Cádiz, Polígono Río San Pedro, s/n, Ap.40, 11510 Puerto Real, Cádiz, Spain

2 Departamento de Biología, Edificio de Biología, Campus de Excelencia Internacional UAM+CSIC, Universidad Autónoma de Madrid, C/Darwin, 2, 28049 Madrid, Spain

3 Department of Invertebrate Zoology, California Academy of Sciences, 55 Music Concourse Drive, Golden Gate Park, San Francisco, CA 94118, USA

\section{Introduction}

Burnaia helicochorda (Miller 1987), originally ascribed to Aeolidia Cuvier, 1798, was considered a member of Aeolidiidae although the author did not provide any reason for that systematic position. According to Miller (1987, 2001), this species was of easy identification by its external colouration, large body, lamellate rhinophores, and cerata in arches. Actually, because of all these morphological aspects, Miller (2001) decided to create a new genus, Burnaia, for this species. Since it was first described, $B$. helicochorda has not been reported many times (Rudman 2001; Grove 2015), and for this reason, Carmona et al. (2013), who conducted a molecular phylogeny of the family Aeolidiidae, could not include material of this not very common aeolid.

Recently collected material form Victoria, Australia, permitted us to study the systematic position of this species. This fresh material allowed us to use a molecular approach as well as to re-examine the morphology and anatomy of B. helicochorda, providing for the first time scanning electron photographs of the radula and jaws.

\section{Materials and methods}

\section{Molecular work}

DNA extraction, amplification, and sequencing

Two specimens of B. helicochorda were studied. One hundred twenty-four additional sequences were obtained from GenBank (see Table 1 for full list of samples, localities, and vouchers). Tritonia challengeriana Bergh, 1884, was chosen as out-group because of its basal 
Table 1 List of specimens used for phylogenetic analyses

\begin{tabular}{|c|c|c|c|c|c|c|c|}
\hline \multirow[t]{2}{*}{ Family } & \multirow[t]{2}{*}{ Species } & \multirow[t]{2}{*}{ Locality } & \multirow{2}{*}{$\begin{array}{l}\text { Collection } \\
\text { dates }\end{array}$} & \multirow[t]{2}{*}{ Voucher } & \multicolumn{3}{|c|}{ GenBank accession Nos. } \\
\hline & & & & & $\mathrm{COI}$ & $16 \mathrm{~S}$ & H3 \\
\hline $\begin{array}{l}\text { Tritoniidae } \\
\text { Lamarck, } 1809\end{array}$ & $\begin{array}{l}\text { Tritonia challengeriana Bergh, } \\
1884\end{array}$ & $\begin{array}{l}\text { Bouvetoya (EA, } \\
\text { GB) }\end{array}$ & 30 Jun 04 & & HM162718 & HM162643 & HM162550 \\
\hline $\begin{array}{l}\text { Dendronotidae } \\
\text { Allman, } 1845\end{array}$ & $\begin{array}{l}\text { Dendronotus venustus } \\
\text { MacFarland, } 1966\end{array}$ & $\begin{array}{l}\text { Santa Monica } \\
\text { (California, } \\
\text { GB) }\end{array}$ & Dec 07 & & HM162709 & HM162630 & HM162536 \\
\hline $\begin{array}{l}\text { Proctonotidae } \\
\text { Gray, } 1853\end{array}$ & $\begin{array}{l}\text { Janolus mirabilis Baba and Abe, } \\
1970\end{array}$ & $\begin{array}{l}\text { Philippines } \\
\text { (GB) }\end{array}$ & 19 May 09 & & HM162750 & HM162674 & HM162583 \\
\hline \multirow[t]{11}{*}{$\begin{array}{l}\text { Aeolidiidae Gray, } \\
1827\end{array}$} & $\begin{array}{l}\text { Aeolidia papillosa (Linnaeus, } \\
\text { 1761) }\end{array}$ & Sweden & 14 Sep 11 & $\begin{array}{l}\text { MNCN/ } \\
\text { ADN: } \\
51929\end{array}$ & JX087534 & JX087462 & JX087596 \\
\hline & Aeolidiella alderi (Cocks, 1852) & France (MED) & $26 \mathrm{Jul} 02$ & $\begin{array}{l}\text { ZSM Mol } \\
20020982\end{array}$ & HQ616765 & HQ616728 & HQ616794 \\
\hline & $\begin{array}{l}\text { Anteaeolidiella cacaotica } \\
\text { (Stimpson, 1855) }\end{array}$ & $\begin{array}{l}\text { Eastern } \\
\text { Australia }\end{array}$ & 14 Feb 10 & $\begin{array}{l}\text { MNCN/ } \\
\text { ADN: } \\
51922\end{array}$ & JX087528 & JX087455 & JX087590 \\
\hline & Baeolidia moebii Bergh, 1888 & Philippines & 16 Apr 08 & $\begin{array}{l}\text { CASIZ } \\
177602\end{array}$ & HQ616770 & HQ616733 & HQ616799 \\
\hline & $\begin{array}{l}\text { Berghia coerulescens (Laurillard, } \\
\text { 1830) }\end{array}$ & Croatia & 03 Dec 04 & $\begin{array}{l}\text { ZSM Mol } \\
20041584\end{array}$ & JQ997049 & JQ996845 & JQ996946 \\
\hline & Bulbaeolidia alba (Risbec, 1928) & Philippines & 21 May 09 & $\begin{array}{l}\text { CASIZ } \\
180387\end{array}$ & JQ997012 & JQ996805 & JQ996904 \\
\hline & $\begin{array}{l}\text { "Cerberilla" annulata (Quoy and } \\
\text { Gaimard, 1832) }\end{array}$ & Marshall Is. & 24 Jul 00 & $\begin{array}{l}\text { CASIZ } \\
182227\end{array}$ & - & JQ996866 & JQ996967 \\
\hline & $\begin{array}{l}\text { "Cerberilla” bernadettae Tardy, } \\
1965\end{array}$ & Spain (EA) & 06 Apr 108 & $\begin{array}{l}\text { MNCN/ } \\
\text { ADN: } \\
51957\end{array}$ & JX087555 & JX087489 & JX087625 \\
\hline & $\begin{array}{l}\text { "Cerberilla" cf. affinis (Quoy and } \\
\text { Gaimard, 1832) }\end{array}$ & Philippines & 16 May 09 & $\begin{array}{l}\text { CASIZ } \\
180421\end{array}$ & - & JQ996863 & JQ996964 \\
\hline & $\begin{array}{l}\text { Limenandra nodosa Haefelfinger } \\
\text { and Stamm, } 1958\end{array}$ & $\begin{array}{l}\text { Balearic Is. } \\
\text { (Spain, MED) }\end{array}$ & Sep 2007 & $\begin{array}{l}\text { MNCN/ } \\
\text { ADN } \\
24.923\end{array}$ & HQ616768 & HQ616731 & HQ616797 \\
\hline & $\begin{array}{l}\text { Spurilla neapolitana (delle Chiaje, } \\
\text { 1841) }\end{array}$ & Italy & 17 Mar 09 & $\begin{array}{l}\text { MNCN/ } \\
\text { ADN: } \\
51976\end{array}$ & JX087584 & JX087521 & JX087659 \\
\hline \multirow[t]{2}{*}{$\begin{array}{l}\text { Babakinidae } \\
\text { Roller, } 1973\end{array}$} & Babakina anadoni (Ortea, 1979) & Brazil & Feb 06 & $\begin{array}{l}\text { MNRJ } \\
10893\end{array}$ & HQ616746 & HQ616709 & HQ616775 \\
\hline & $\begin{array}{l}\text { Babakina indopacifica Gosliner, } \\
\text { González-Duarte and Cervera, } \\
2007\end{array}$ & $\begin{array}{l}\text { Philippines } \\
\text { (GB) }\end{array}$ & 20 Mar 08 & - & HM162754 & HM162678 & HM162587 \\
\hline \multirow[t]{6}{*}{$\begin{array}{l}\text { Facelinidae } \\
\text { Bergh, } 1889\end{array}$} & $\begin{array}{l}\text { Burnaia helicochorda Miller, } \\
1987\end{array}$ & $\begin{array}{l}\text { Victoria, } \\
\text { Australia }\end{array}$ & 26 Oct 07 & $\begin{array}{l}\text { NMV } \\
\text { F152957 }\end{array}$ & - & - & KT200150 \\
\hline & & $\begin{array}{l}\text { Victoria, } \\
\text { Australia }\end{array}$ & 13 Feb 08 & $\begin{array}{l}\text { NMV } \\
\text { F155816 }\end{array}$ & KT200148 & KT200147 & KT200149 \\
\hline & Cratena peregrina Gmelin, 1791 & Senegal & 30 May 05 & $\begin{array}{l}\mathrm{MNCN} \\
15.05 / \\
53691\end{array}$ & HQ616752 & HQ616715 & HQ616781 \\
\hline & $\begin{array}{l}\text { Dondice banyulensis Portmann } \\
\text { and Sandmeier, } 1960\end{array}$ & Spain (EA) & 26 May 09 & $\begin{array}{l}\mathrm{MNCN} \\
15.05 / \\
53693\end{array}$ & - & HQ616740 & HQ616804 \\
\hline & & $\begin{array}{l}\text { Spain (MED, } \\
\text { GB) }\end{array}$ & - & - & AF249782 & - & - \\
\hline & $\begin{array}{l}\text { Facelina annulicornis (Chamisso } \\
\text { and Eysenhardt, 1821) }\end{array}$ & $\begin{array}{l}\text { Azores Is. } \\
\text { (Portugal) }\end{array}$ & 11 Jun 02 & $\begin{array}{l}\text { CASIZ } \\
186793\end{array}$ & JQ997076 & JQ996881 & JQ996986 \\
\hline
\end{tabular}


Table 1 continued

\begin{tabular}{|c|c|c|c|c|c|c|c|}
\hline \multirow[t]{2}{*}{ Family } & \multirow[t]{2}{*}{ Species } & \multirow[t]{2}{*}{ Locality } & \multirow{2}{*}{$\begin{array}{l}\text { Collection } \\
\text { dates }\end{array}$} & \multirow[t]{2}{*}{ Voucher } & \multicolumn{3}{|c|}{ GenBank accession Nos. } \\
\hline & & & & & $\mathrm{COI}$ & $16 \mathrm{~S}$ & $\mathrm{H} 3$ \\
\hline & $\begin{array}{l}\text { Favorinus branchialis (Rathke, } \\
\text { 1806) }\end{array}$ & Spain (EA) & 26 Jun 07 & $\begin{array}{c}\text { MNCN } \\
15.05 / \\
53695\end{array}$ & HQ616761 & HQ616724 & HQ616790 \\
\hline & $\begin{array}{l}\text { Favorinus elenalexiarum García } \\
\text { and Troncoso, } 2001\end{array}$ & $\begin{array}{l}\text { Costa Rica (EP, } \\
\text { GB) }\end{array}$ & 17 Apr 07 & - & HM162755 & HM162679 & HM162588 \\
\hline & $\begin{array}{l}\text { Godiva quadricolor (Barnard, } \\
\text { 1927) }\end{array}$ & $\begin{array}{l}\text { South Africa } \\
\text { (EA, GB) }\end{array}$ & 09 Jan 08 & - & HM162692 & HM162602 & HM162508 \\
\hline & $\begin{array}{l}\text { Hermosita hakunamatata (Ortea, } \\
\text { Caballer and Espinosa, 2003) }\end{array}$ & Mexico & 17 Feb 06 & $\begin{array}{l}\text { CASIZ } \\
174088\end{array}$ & KP143674 & KP143670 & KP143678 \\
\hline & Moridilla brockii Bergh, 1888 & Philippines & 29 Apri 11 & $\begin{array}{l}\text { CASIZ } \\
186245\end{array}$ & JQ997083 & JQ996888 & JQ996994 \\
\hline & $\begin{array}{l}\text { Noumeaella isa Marcus and } \\
\text { Marcus, } 1970\end{array}$ & Philippines & 01 May 11 & $\begin{array}{l}\text { CASIZ } \\
186249\end{array}$ & JQ997084 & JQ996889 & JQ996995 \\
\hline & Phidiana lynceus Bergh, 1867 & Cuba & $21 \mathrm{Jul} 08$ & $\begin{array}{c}\text { MNCN/ } \\
\text { ADN: } \\
51995\end{array}$ & JX087562 & JX087497 & JX087633 \\
\hline & $\begin{array}{l}\text { Phyllodesmium horridum } \\
\text { (Macnae, 1954) }\end{array}$ & $\begin{array}{l}\text { South Africa } \\
(\text { EA, GB) }\end{array}$ & 03 Jan 08 & - & HM162757 & HM162681 & HM162590 \\
\hline & Pleurolidia juliae Burn, 1966 & Philippines & 05 May 05 & $\begin{array}{l}\text { CASIZ } \\
186217\end{array}$ & JQ997094 & JQ996899 & JQ997007 \\
\hline & Protaeolidiella atra Baba, 1955 & Japan & 17 Feb 04 & $\begin{array}{l}\text { NSMT-Mo } \\
78853\end{array}$ & KP143676 & KP143672 & KP143680 \\
\hline & & Japan & 18 Feb 04 & $\begin{array}{l}\text { NSMT-Mo } \\
78852\end{array}$ & KP143675 & KP143671 & KP143679 \\
\hline & $\begin{array}{l}\text { Pruvotfolia longicirrha (Eliot, } \\
\text { 1906) }\end{array}$ & Cape Verde & Mar 10 & $\begin{array}{r}\text { MNCN } \\
15.05 / \\
53703\end{array}$ & HQ616760 & HQ616723 & HQ616789 \\
\hline & $\begin{array}{l}\text { Pruvotfolia pselliotes (Labbé, } \\
\text { 1923) }\end{array}$ & France (EA) & 05 Sep 04 & $\begin{array}{c}\text { MNCN } \\
15.05 / \\
53705\end{array}$ & HQ616762 & HQ616725 & HQ616791 \\
\hline & $\begin{array}{l}\text { Sakuraeolis enosimensis (Baba, } \\
\text { 1930) }\end{array}$ & California (GB) & 13 Dec 07 & - & HM162758 & HM162682 & HM162591 \\
\hline $\begin{array}{l}\text { Fionidae Alder } \\
\text { and Hancock, } \\
1855\end{array}$ & Fiona pinnata (Eschscholtz, 1831) & Morocco (EA) & 22 Dec 10 & $\begin{array}{c}\text { MNCN/ } \\
\text { ADN: } \\
51997\end{array}$ & JX087558 & JX087492 & JX087628 \\
\hline \multirow[t]{5}{*}{$\begin{array}{l}\text { Flabellinidae } \\
\text { Bergh, } 1881\end{array}$} & Flabellina affinis (Gmelin, 1791) & $\begin{array}{l}\text { Balearic Is. } \\
\text { (Spain, MED) }\end{array}$ & 14 Jul 07 & $\begin{array}{l}\text { MNCN } \\
15.05 / \\
53696\end{array}$ & HQ616753 & HQ616716 & HQ616782 \\
\hline & Flabellina babai Schmekel, 1972 & $\begin{array}{l}\text { Chafarinas Is. } \\
\text { (MED) }\end{array}$ & 25 Feb 07 & $\begin{array}{c}\mathrm{MNCN} \\
15.05 / \\
53698\end{array}$ & HQ616754 & HQ616717 & HQ616783 \\
\hline & $\begin{array}{l}\text { Flabellina baetica García-Gómez, } \\
1984\end{array}$ & Spain (EA) & 14 Jan 05 & $\begin{array}{c}\text { MNCN } \\
15.05 / \\
53699\end{array}$ & HQ616755 & HQ616718 & HQ616784 \\
\hline & $\begin{array}{l}\text { Flabellina ischitana Hirano and } \\
\text { Thompson, } 1990\end{array}$ & Morocco (EA) & 07 Mar 08 & $\begin{array}{c}\text { MNCN } \\
15.05 / \\
53700\end{array}$ & HQ616756 & HQ616719 & HQ616785 \\
\hline & $\begin{array}{l}\text { Flabellina pedata (Montagu, } \\
\text { 1815) }\end{array}$ & Spain (MED) & 13 Oct 07 & $\begin{array}{c}\mathrm{MNCN} \\
15.05 / \\
53702\end{array}$ & HQ616758 & HQ616721 & HQ616787 \\
\hline
\end{tabular}


Table 1 continued

\begin{tabular}{|c|c|c|c|c|c|c|c|}
\hline \multirow[t]{2}{*}{ Family } & \multirow[t]{2}{*}{ Species } & \multirow[t]{2}{*}{ Locality } & \multirow{2}{*}{$\begin{array}{l}\text { Collection } \\
\text { dates }\end{array}$} & \multirow[t]{2}{*}{ Voucher } & \multicolumn{3}{|c|}{ GenBank accession Nos. } \\
\hline & & & & & $\mathrm{COI}$ & $16 \mathrm{~S}$ & $\mathrm{H} 3$ \\
\hline \multirow[t]{3}{*}{$\begin{array}{l}\text { Piseinotecidae } \\
\text { Edmunds, } 1970\end{array}$} & $\begin{array}{l}\text { Piseinotecus gabinieri (Vicente, } \\
\text { 1975) }\end{array}$ & Spain (MED) & 13 Oct 07 & $\begin{array}{c}\text { MNCN/ } \\
\text { ADN: } \\
52000\end{array}$ & JX087561 & JX087495 & JX087631 \\
\hline & $\begin{array}{l}\text { Piseinotecus gaditanus Cervera, } \\
\text { García-Gómez and García, } 1987\end{array}$ & Spain (EA) & 20 Jun 07 & $\begin{array}{r}\text { MNCN } \\
15.05 / \\
53704\end{array}$ & HQ616759 & HQ616722 & HQ616788 \\
\hline & Piseinotecus sp. & $\begin{array}{l}\text { Philippines } \\
\text { (GB) }\end{array}$ & 22 Apr 08 & - & HM162694 & HM162604 & HM162510 \\
\hline
\end{tabular}

$A T L$ Atlantic Ocean, EA eastern Atlantic Ocean, EP eastern Pacific, GB GenBank, $M E D$ Mediterranean

phylogenetic position within Cladobranchia (Pola and Gosliner 2010). Tissue samples were taken from the foot. Extraction, amplification, purification, and sequencing of portions of the COI, 16S rRNA, and H3 genes followed the methods described in Carmona et al. (2013, 2014a, b). Sequence reactions were run on a 3730XL DNA sequencer (Applied Biosystems). Sequences were verified by forward and reverse comparisons and have been deposited in GenBank (Table 1).

\section{Sequence alignment and phylogenetic analyses}

Sequences were assembled and edited with Geneious Pro version 4.7.6 (Drummond et al. 2009), aligned in MAFFT (Katoh et al. 2009), and further checked using MacClade version 4.06 (Maddison and Maddison 2005). The most variable regions from the $16 \mathrm{~S}$ rRNA alignment were removed using the default settings in Gblocks (Talavera and Castresana 2007). Excluding "indel-rich" regions, the tree was in general very similar when including the variable regions. Therefore, final analyses were performed including all bases. Sequences of COI, 16S, and H3 were trimmed to 657,445 , and 327 base pairs, respectively.

The best-fit evolutionary model (GTR $+\mathrm{I}+\mathrm{G}$ for the three genes) was determined in MrModeltest version 2.3 (Nylander 2004), using the Akaike information criterion (Akaike 1974). MrBayes version 3.1.2 (Ronquist and Huelsenbeck 2003) was used for Bayesian inference analysis and to estimate posterior probabilities (PP) for node support with two runs of 10,000,000 generations each. Convergence was checked in TRACER version 1.5 (Drummond and Rambaut 2007) with a burn-in of $25 \%$. Maximum likelihood (ML) analyses were performed using the software RAxML version 7.0.4 (Stamatakis 2006), and node support was assessed with nonparametric bootstrapping (BS) with 5000 replicates, random starting trees, and parameters estimated from each data set under the model selected for the original data set. Only nodes supported by BS $\geq 70$ (Hillis and Bull 1993) and PP $\geq 0.95$ (Alfaro et al. 2003) are discussed.

\section{Source of specimens and morphology}

The specimens studied were borrowed from the Museum Victoria (Melbourne, Australia). Specimens were dissected by dorsal incision. Their internal features were examined and drawn under a stereoscopic microscope with the aid of a camera lucida. The buccal mass was removed and soaked in a $10 \%$ sodium hydroxide solution to dissolve the connective and muscle tissue, leaving only the radula and jaws. Both, radula and jaws, were then rinsed in water, dried, and mounted for examination under a scanning electron microscopy (SEM).

\section{Results}

\section{Phylogenetic analysis}

The combined data set yielded a sequence alignment of 1429 positions. No saturation was observed across genes and codon positions, not even in the third position (not shown). The resulting combined tree provided better resolution than H3, COI, or $16 \mathrm{~S}$ separately (not shown). Figure 1 shows the phylogenetic hypothesis based on the combined data set constructed by Bayesian inference. The topology of the ML tree was identical (not shown), although the bootstrap values were lower than the PP in deeper nodes.

Burnaia helicochorda and the remaining species of Aeolidiidae included in this study clustered in two distinct and well-separated clades $(\mathrm{PP}=1, \mathrm{BS}=100$, and $\mathrm{PP}=0.99$, BS $=72$, respectively). B. helicochorda were nested among different facelinid species $(\mathrm{PP}=0.99$, 


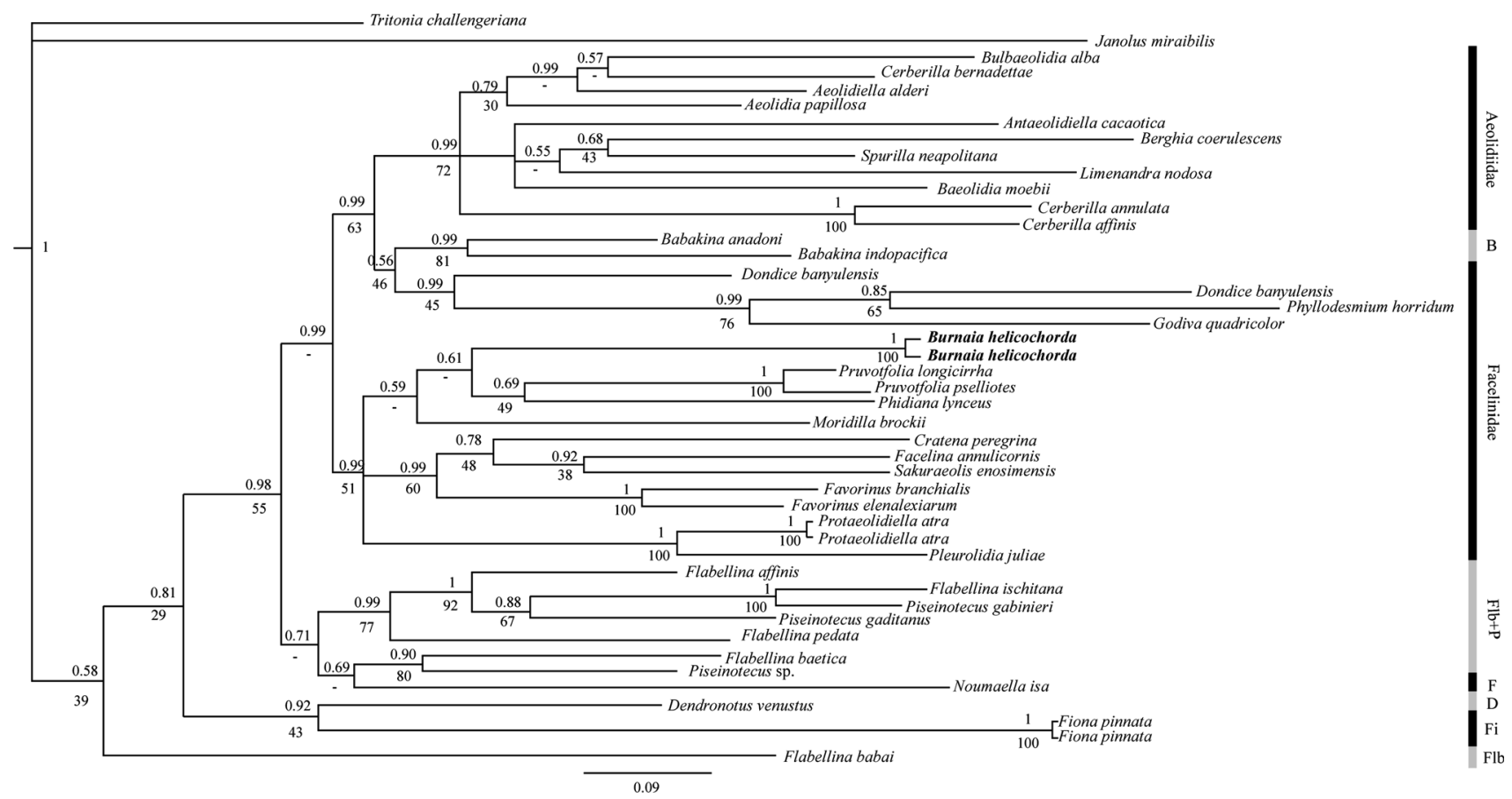

Fig. 1 Phylogenetic hypothesis for B. helicochorda based on the combined data set $(\mathrm{H} 3+\mathrm{COI}+16 \mathrm{~S})$ inferred by Bayesian analysis (BI). Numbers above branches represent posterior probabilities from

BS = 51): Pruvotfolia longicirrha (Eliot, 1906), P. pselliotes (Labbé, 1923), Phidiana lynceus Bergh, 1867, Moridilla brockii Bergh, 1888, Cratena peregrina (Gmelin, 1791), Facelina annulicornis (Chamisso and Eysenhardt, 1821), Sakuraeolis enosimensis (Baba, 1930), Favorinus branchialis (Rathke, 1806), Favorinus elenalexiarum Garcia and Troncoso, 2001, Protaeolidiella atra Baba, 1955 and Pleurolidia juliae Burn, 1966. However, the relationships between them were not resolved, and Facelinidae was not recovered as monophyletic.

Diagnosis of Burnaia following Miller (2001):

Body long, narrow, oral tentacles moderately long, tapered, rhinophores longish, lamellate almost to base; cerata cylindrical, long, mobile (diverticula loosely spiralled), arranged in horseshoe-shaped arches, in single rows; cleioproctic, anus in centre of second arch, renal pore abanal, immediately in front of arch, reproductive apertures at tip of rear limb of first arch; foot narrow, rounded at front end extending as short, blunt lobes; oral glands small, club-shaped; radular tooth a very low, wide arch, blade narrowish, denticles almost uniform; jaw masticatory process complexly denticulate.

Burnaia helicochorda (Miller 1987)

(Figure 2)

Aeolidia helicochorda Miller 1987: 391, figs. 1-5.
BI. Numbers below branches represent bootstrap values from ML. B. helicochorda specimens in bold. B Babakinidae, Fbl Flabellinidae, $P$ Piseinotecidae, $F$ Facelinidae, $D$ Dendronotidae, $F i$ Fionidae

Type locality: Goat Island Bay, New Zealand.

Type material: The holotype was deposited at the Museum of New Zealand (M.87451) (Miller (1987).

Material examined (NMV F155816), one specimen, adult, mature, partially dissected, $11 \mathrm{~mm}$ in length preserved, Victoria, Australia, collected by Leon Altoff, 13.ii.08; (NMV F152957), one specimen, adult, mature, $5 \mathrm{~mm}$ in length preserved, Victoria, Australia, collected by Leon Altoff, 26.x.07.

Geographical distribution Originally described from North of New Zealand (Miller 1987), this species has been also reported in eastern Australia (Rudman 2001; present study) and Tasmania (Grove 2015).

External morphology (Fig. 2a, b) The body is elongate and narrow when fully extended, tapering gradually to the fairly short tail. The foot corners are rounded. The body colour is translucent white, but the dorsal surface may have orange pigmentation, which is denser from the area immediately posterior to the head to the posterior end of the body. The rhinophores, oral tentacles, and foot corners are also covered with orange. From the anterior base of the rhinophores to the edge of the head, there is longitudinal orange band that joins a U-shaped mark, which surrounds the edge of the head and runs forward to the base of the oral tentacles. The rhinophores, which are a bit shorter than the oral tentacles, are 

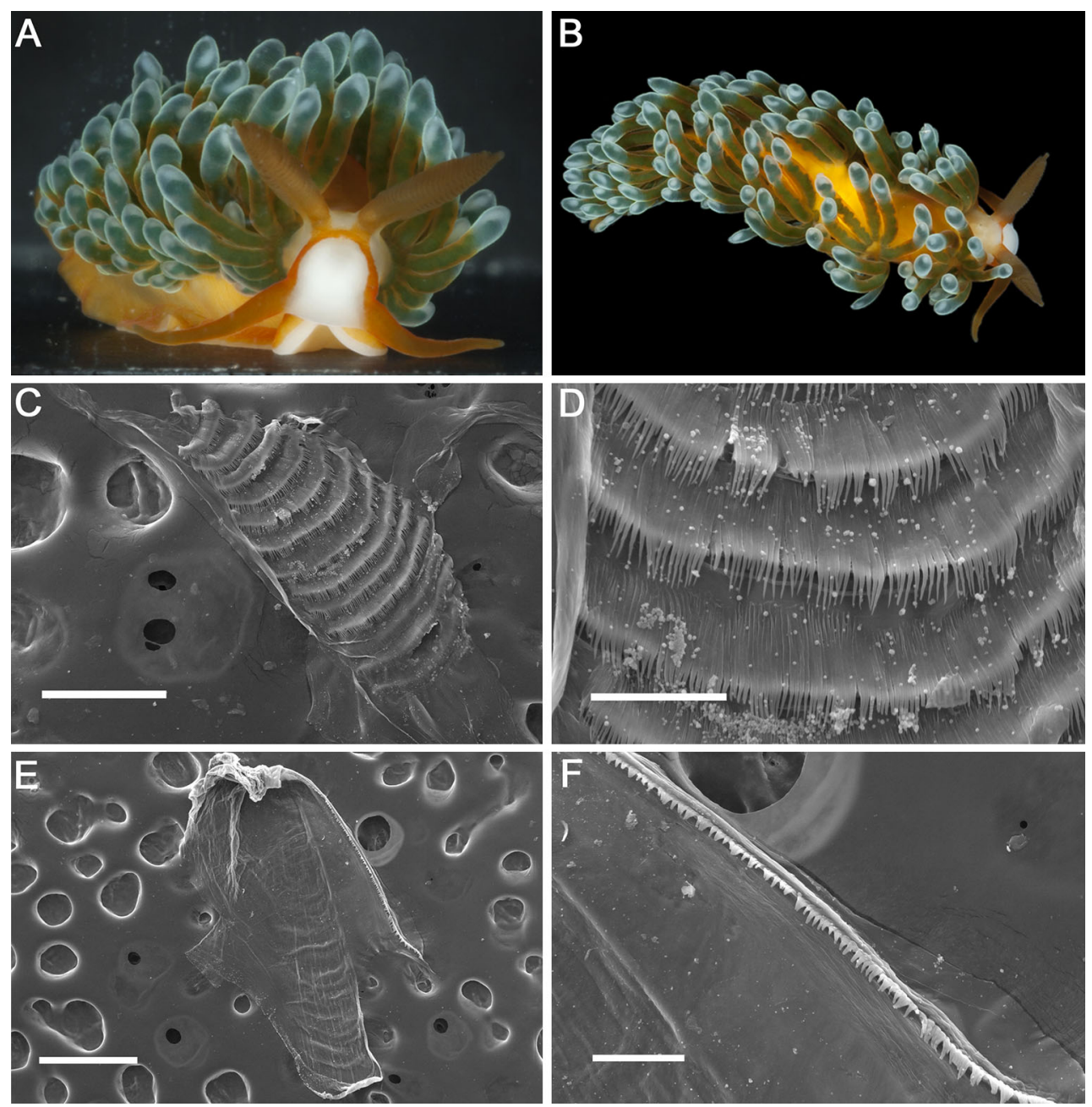

Fig. 2 Burnaia helicochorda (Miller 1987). a, b Frontal and dorsal view of the living animal, photograph by L. Altoff. c, d Scanning electron photographs (NMV F155816). $\mathbf{c}$ General view of the radula,

perfoliate, bearing up to 18 lamellae. A pair of black eyes is visible at the posterior side of the rhinophores base.

The cerata are arranged in arches, with gaps between the arches that decrease posteriorly. Each arch contains between two and 11 cerata. They extend from behind the rhinophores to the posterior end of the body. The ceratal length is variable, but all are slender, cylindrical, with a small swelling at the apical part. The cerata are translucent, but covered by orange pigmentation. The olive green ramifications of the digestive gland are visible through the ceratal wall and have several constrictions over their length. The distal $1 / 3$ of the cerata is opaque greyish green. On the right side of the body, the gonopore is situated among the cerata of the anteriormost group. The anus is on the right side of the body, in a cleioproctic position, located within the second ceratal arch.

Anatomy (Fig. 2c-f) The radula is uniseriate $(11 \times 0.1 .0$, NMV F155816). The teeth decrease in size

scale bar $125 \mu \mathrm{m}$. d Radular teeth, scale bar $75 \mu \mathrm{m}$. e Complete view of the jaw, scale bar $0.5 \mathrm{~mm}$. f Detailed view of the masticatory border, scale bar $125 \mu \mathrm{m}$

towards the posterior region of the radula (Fig. 2c). The radular teeth are pectinate with 58-124, fine, elongate, and acutely pointed denticles (Fig. 2d). The jaws are translucent and oval (Fig. 2e). The masticatory border of the jaws is finely denticulate (Fig. 2f). The oral glands occur dorsolaterally to the buccal bulb. They are moderately short and increase in size towards the posterior end. Salivary glands were not observed.

The reproductive system was not examined so as not to damage the specimen, but was described in detail by Miller (1987, Fig. 5).

\section{Discussion}

The inclusion of $B$. helicochorda within the paraphyletic Facelinidae represents an intriguing and unexpected outcome. As Miller $(1987,2001)$ pointed out, in body shape $B$. 
helicochorda resembles Limenandra nodosa and L. fusiformis. In addition, the pectinate radula could be considered as the typical radula of the Aeolidiidae members (Carmona et al. 2014a, b, c). However, our molecular study separates $B$. helicochorda from Aeolidiidae and places it in a clade composed by facelinids. Carmona et al. (2013) and more recently Carmona et al. (2015) found out a similar situation with the species $P$. atra and $P$. juliae, formerly considered as primitive members of Aeolidiidae and now clearly situated within Facelinidae. This last outcome was supported by the feeding habits of these two species, since they prey on hydroids instead of sea anemones and other anthozoans that represent the characteristic prey of aeolidiids (Gosliner et al. 2008; Carmona et al. 2013). Nevertheless, we were unable to find information about the diet of B. helicochorda. Finally, in terms of morphology and internal anatomy, our study suggests re-evaluation of the apparent morphological synapomorphies that have traditionally united the aeolidid genera and species is needed. A more general and comprehensive revision of the Facelinidae and Aeolidida is also necessary given the fact that Facelinidae is not monophyletic (Carmona et al. 2013, 2015; present study).

Acknowledgments We are deeply grateful to R. Wilson and L. Altoff who helped to provide specimens and images, respectively, for this study. This work was supported by the research Grant (CGL201017187), Spanish Ministry of Economy and Competitiveness (includes the early Ministry of Sciences and Innovation), to J. L. Cervera. This is CEI.MAR journal publication 101.

\section{References}

Akaike H (1974) A new look at the statistical model identification. IEEE Trans Autom Control 19:716-723

Alfaro ME, Zoller S, Lutzoni F (2003) Bayes or bootstraps? A simulation study comparing the performance of Bayesian Markov chain Monte Carlo sampling and bootstrapping in assessing phylogenetic confidence. Mol Biol Evol 20:255-266

Carmona L, Pola M, Gosliner TM, Cervera L (2013) A tale that morphology fails to tell: a molecular phylogeny of Aeolidiidae (Aeolidida, Nudibranchia, Gastropoda). PLoS ONE 8:e63000. doi:10.1371/journal.pone. 0063000

Carmona L, Bhave V, Salunkhe R, Pola M, Gosliner TM, Cervera JL (2014a) Systematic review of Anteaeolidiella (Mollusca, Nudibranchia, Aeolidiidae) based on morphological and molecular data, with a description of three new species. Zool J Linn Soc 171:108-132
Carmona L, Lei BR, Pola M, Gosliner TM, Valdés Á, Cervera JL (2014b) Untangling the Spurilla neapolitana (Delle Chiaje, 1841) species complex: a review of the genus Spurilla Bergh, 1864 (Mollusca: Nudibranchia: Aeolidiidae). Zool J Linn Soc 171:132-154

Carmona L, Pola M, Gosliner TM, Cervera JL (2014c) Review of Baeolidia, the largest genus of Aeolidiidae (Mollusca: Nudibranchia), with the description of five new species. Zootaxa 3802:477-514

Carmona L, Pola M, Gosliner TM, Cervera L (2015) Protaeolidiella atra Baba, 1955 versus Pleurolidia juliae Burn, 1966: one or two species? Helgol Mar Res. doi:10.1007/s10152-014-0422-3

Drummond AJ, Rambaut A (2007) BEAST: Bayesian evolutionary analysis by sampling trees. BMC Evol Biol 7:214

Drummond AJ, Ashton B, Cheung M, Heled J, Kearse M, Moir R, Stones-Havas S, Thierer T, Wilson A (2009) Geneious v4.6. Ghiselin. http://www.geneious.com/

Gosliner TM, Behrens DW, Valdés Á (2008) Indo-Pacific nudibranchs and sea slugs. Sea Challengers, California Academy of Sciences, Gig Harbor, San Francisco, CA

Grove S (2015) Burnaia helicochorda (Miller, 1988). In: A guide to the seashells and other marine molluscs of Tasmania. http:// www.molluscsoftasmania.net/Species\%20pages/Burnaia\%20heli cochorda.html

Hillis DM, Bull JJ (1993) An empirical test of bootstrapping as a method for assessing confidence in phylogenetic analysis. Syst Biol 42:182-192

Katoh K, Asimenos G, Toh H (2009) Multiple alignment of DNA sequences with MAFFT. In: Posada D (ed) Bioinformatics for DNA sequence analysis. Methods Mol Biol 537:39-64

Maddison DR, Maddison WP (2005) MacClade 4., v. 4.08 for OSX. Sinauer Associates, Sunderland

Miller MC (1987) Aeolidia helicochorda, a new aeolid nudibranch (Gastropoda: Opisthobranchia) from New Zealand. N Z J Zool 14:391-397

Miller MC (2001) Aeolid nudibranchs (Gastropoda: Opisthobranchia) of the family Aeolidiidae from New Zealand waters. J Nat Hist 35:629-662

Nylander JAA (2004) MrModeltest v2.3. Program distributed by the author. Evolutionary Biology Centre, Uppsala University

Pola M, Gosliner TM (2010) The first molecular phylogeny of cladobranchian opisthobranchs (Mollusca, Gastropoda, Nudibranchia). Mol Phylogenet Evol 56:931-941

Ronquist F, Huelsenbeck JP (2003) MrBayes 3: Bayesian phylogenetic inference under mixed models. Bioinformatics 19:1572-1574

Rudman WB (2001) Burnaia helicochorda (Miller, 1988). In: Sea slug forum. Australian Museum, Sydney. http://www.seaslug forum.net/factsheet/burnheli

Stamatakis A (2006) RAxML-VI-HPC: maximum likelihood-based phylogenetic analyses with thousands of taxa and mixed models. Bioinformatics 22:2688-2690

Talavera G, Castresana J (2007) Improvement of phylogenies after removing divergent and ambiguously aligned blocks from protein sequence alignments. Syst Biol 56:564-577 